\title{
Risk Management Course System
}

\section{In Application-Oriented University: An "1+2" Mode}

\author{
Yin YU \\ College of Arts and Sciences \\ Shanghai Second Polytechnic University \\ Shanghai, China \\ yuyin@sspu.edu.cn
}

\begin{abstract}
Risk management has become the effective management methods of the government, enterprise, family and individual in preventing, reducing risk accident and the loss rate. Combing the standards and frameworks widely accepted by the domestic and international risk management and summarizing education situation, this paper thinks that the problems of risk management course in China are a lack of overall design, no match existing standards and the framework, the single of content and method, regard theory belittle applications, as well as a lack of the introduction and application of information system and auxiliary software. Thus, this paper introduces the "1 $+2 "$ model in which curriculum standard is at the core, the standard of teaching quality and learning objects quality is as the wings. This model is great for the overall thinking about consistency of standards, textbooks, teaching and evaluation.
\end{abstract}

Keywords-Risk Management; Course Construction, AppliedOriented Undergraduate; Mode.

\section{INTRODUCTION}

In today's society, the risk is everywhere, and importance of risk management is growing. Under the background of economic globalization and industrialization, the risk management has become the operational management method for preventing, reducing risk accident and the loss rate for government, enterprise, family and individual. To realize the effective risk management is the key of complete risk management by clearing up risks existence, using mechanism and framework being processed and dealt with uncertainty factors, adopting the method of systematic, comprehensive and flexible tools and techniques to make relatively accurate and rapid assessment for risk [1]. Efficient risk management cannot come off the high-quality professionals.

Throughout the history of development and discipline education of risk management in China, opposed to other countries, it was started relatively late. Research became less about the course and the teaching of risk management [2]. To fusion and cross of multi-disciplinary knowledge in mathematics, statistics, economics, management science and so on, knowledge system of risk management is complex [3]. And its practical is the case that. Therefore, it has positive practical significance to grasp content and direction of talent training of the risk management, clarify the key point of the basic theory, basic knowledge and basic skills on the whole for improving the personnel quality of risk management.
As the breakthrough point, this paper teased out the risk management standards of the domestic and the foreign. Then, the present situation of domestic and international education of risk management was presented, and problems existing in the education of our country's risk management were reviewed. Based on this, this paper put forward a "1+2" model framework of the risk management course system.

\section{STANDARD OF RISK MANAGEMENT}

In 1931, American Management Association's Insurance Department proposed firstly the concept on the risk management, and focused on the problem of risk management and insurance in the form of academic conference and seminar in the later years. In 1932, the Risk and Insurance Management Society (RIMS), a national professional society, was founded in the United States, in that most of the risk managers of enterprise became its members. Next, in Britain, France, Germany, Japan and other countries, national and regional risk management association had established one after another. The application of risk management had spread to all kinds of enterprises. They established the risk management department, but also looked as an important functional department [4-6].

At the RIMS annual meeting in the United States in 1983, experts and scholars discussed the adoption of "101 Risk Management Guidelines", which marked the risk management had entered a new stage of development. Under this guideline, some countries or organizations have introduced a series of risks management standards and frameworks, such as the COSO Internal Control Certificate (1992, 2004,2013) being widely accepted within the industry, IRM Standard (2002), ISO3100 (2009), British Standard BS31100 (2011) and so on (table 1, in which the British Standard BS31100 and ISO3100 are extremely close, not listed), to describe the content of the risk management framework and regulate the risk management process.

China's study on risk management began in the 1980s. In 1997, Asian financial crisis had become the development opportunity of domestic risk management. From the financial risk study, a large number of risk management theory and technology to the world synchronized were introduced and applied in China [5,6]. On the basis of the international accepted standards, China also has promulgated the national standard, such as "Risk management-terminology", "Risk 
management-principles and guidelines on implementation", "Supply chain risk management guidelines", "Guidelines for corporate governance risk management" and so on. In 2006, SASAC promulgated the "Central Enterprise comprehensive risk management guidance", further standardized the central enterprise risk management key terminology and management process, and present the seven elements of the risk management process (TABLE 1). It marked China's risk management theory and practice into a new historical stage. Since 2008, several ministries promulgated the policy and regulation on the overall risk management of central enterprises, and expressed great concern about the internal control and overall risk management of central enterprises from the national policy level.

TABLE I. Several STANDARDS and frameworks of risk management

\begin{tabular}{|c|c|c|c|}
\hline COSO & IRM & ISO3100 & $\begin{array}{c}\text { China Central } \\
\text { Enterprise }\end{array}$ \\
\hline $\begin{array}{c}\text { Control } \\
\text { Environment }\end{array}$ & $\begin{array}{c}\text { Strategic } \\
\text { objectives }\end{array}$ & $\begin{array}{c}\text { Communication } \\
\text { and } \\
\text { Consultation }\end{array}$ & Environment \\
\hline Risk Assessment & $\begin{array}{c}\text { Risk } \\
\text { Assessment }\end{array}$ & $\begin{array}{c}\text { Establishing the } \\
\text { Context }\end{array}$ & $\begin{array}{c}\text { Risk } \\
\text { Identification }\end{array}$ \\
\hline $\begin{array}{c}\text { Control } \\
\text { Activities }\end{array}$ & $\begin{array}{c}\text { Risk } \\
\text { Evaluation }\end{array}$ & $\begin{array}{c}\text { Risk } \\
\text { Assessment }\end{array}$ & Risk Analysis \\
\hline $\begin{array}{c}\text { Information \& } \\
\text { Communication }\end{array}$ & $\begin{array}{c}\text { Risk } \\
\text { Reporting }\end{array}$ & Risk Treatment & $\begin{array}{c}\text { Risk } \\
\text { Assessment }\end{array}$ \\
\hline $\begin{array}{c}\text { Monitoring } \\
\text { Activities }\end{array}$ & Decision & $\begin{array}{c}\text { Monitoring and } \\
\text { Review }\end{array}$ & Risk Treatment \\
\hline & $\begin{array}{c}\text { Risk } \\
\text { Treatment }\end{array}$ & & Monitoring \\
\hline & $\begin{array}{c}\text { Residual Risk } \\
\text { Reporting }\end{array}$ & $\begin{array}{c}\text { Information \& } \\
\text { Communication }\end{array}$ \\
\hline & Monitoring & & \\
\hline \multicolumn{3}{|c|}{} \\
\hline
\end{tabular}

\section{EDUCATION OF RISK MANAGEMENT}

\section{A. The Situation of Risk Management Education at Home and Abroad}

In 1960, New York branch of the American Society of Insurance Management (ASIM) and Upasla University cooperated in a risk management course in the Department of Enterprise Management, marking the formal formation of risk management as a new management science in the United States. By in the 1970 of the 20th century, this course was usually opened in most of the universities in the United States, and trained a large number of risk managers [7-9]. In addition, the American Insurance Institute in Pennsylvania hosted the Risk Management Qualification examination, which was awarded the ARM degree certificate. This certificate is recognized in both the United States and Western countries and is regarded as one of the essential conditions for risk managers. The United States published some of the more authoritative risk management textbooks, such as "Risk Management: Tutorial and Case", "Risk Management and Insurance", "Risk Management Procedures" and so on, and established some professional journal of risk Management, such as "Risk Management", "Risk Analysis" and so on.

Education of risk management disciplines was started fairly late in China. At the beginning of 2000, China established the Chinese Institute of Professional Risk Manager, with seminars and training related to the social risk management, with professional certification examination. In recent years, many universities also set up risk management courses in the economic management major, as well as the statistics in science. As a subject, the content of research and teaching was more concentrated in following fields: financial risk, credit risk, venture capital, high-tech enterprise and technology innovation, human resource and Enterprise survival risk, etc. [9-11]. Among other things, most application is in financial investment, which is also glimpsed from textbooks published in China. Many excellent textbooks of risk management were published.

\section{B. Problems of Risk Management in Curriculum Construction in China}

The situation on course construction of risk management is taken into account in published textbooks in China. At present, the overwhelming majority in them fall into the qualitative introduction of the basic theories and knowledge of risk management about basic concepts, steps, then qualitative or quantitative introduction of risk models, including market risk, credit risk, operational risk, liquidity risk, reputation risk, insurance risk. This is also the selection of most business schools, school of economic \& management and statistical specialty in Science.

Risk management involves many disciplines such as math, statistics, economics, and management, finance etc., so that its knowledge system is complex, and the actual operation is complex. There are four prominent problems in the following aspects:

(1) Seriously out of touch with internationally recognized standards and frameworks of risk management.

(2) Lacking of overall design of course, and more coincidence with financial risk management, credit risk management in content.

(3) Regarding theory and belittling application. In teaching, the basic knowledge and theory of risk management are mainly qualitative, and quantitative models are given some introduction theoretically instead of their application. This is clearly not suitable for practice, and not to meet the needs of the large data environment.

(4) The introduction and use of risk management information system or auxiliary software are less. In recent years, many large companies in the United States have adopted risk management information systems (RMIS) to record, track and analyze losses. For example, it is relatively popular and high acceptance that Crystal ball, @Risk, ModelRisk and other risk management software are employed to measure and manage risk in a foreign enterprise. With the development of big data, various companies' RMIS systems are also constantly acquiring data and information from the Internet, and using mathematical analysis techniques to help the in-depth understanding of the problem [11]. In China, the software is not widely used, but also rarely introduced in detail.

We know that the definition and connotation to risk event of different occupational or professional are different. On college education, undergraduate teaching cultivates awareness of risk management and risk management skills. Therefore, the 
design of curriculum system of risk management should be considered in all areas of general techniques and methods, to grasp the basic idea of them, mainly in data analysis, and to emphasize training of basic skills.

\section{The "1+2" Model of Risk Management Course SYSTEM}

Based on the above problems, this paper argues that we can study in depth of the international, national or industry standards. Then, "1+2" standard model is built to perfect and deepen the knowledge system of risk management, to cultivate risk management talents which can respond to the needs of enterprise development. Based on the existing risk management standards and frameworks, "1+2" model refers to the standard and evaluation of curriculum system according to the actual needs of society and the characteristics of cultivating objects. Among them, the"1" is the curriculum standard; the"2" is the teaching quality standard and study quality standard of the training object. In "1+2" standard model, the application is the leading, and the core content includes the basic process, the fundamental knowledge and the basic skill of the specialty, the quantitative research of the data analysis. The teaching goal originates from the curriculum standard, and the appraisal design precedes the teaching design and the study quality of the training object [12]. For this reason, this paper finds that it can be made from three aspects in standard setting, curriculum content development and teaching process (TABLE 2).

Standard-setting. The "1" in "1+2" mode---curriculum standards provides courses nature, course objectives, content, and implementation recommendations of risk management, and defines its basic concepts, as well as learning basic requirements for training of the whole object. Based on curriculum standards, the "2"---teaching quality standard and training quality standard clearly show contents of the courses, level of training, and the performance quality of curriculum standards.

Course content development. In a combination of theory and application, under the principle of combining science and acceptability, teaching ideas are prepared both individualized and creative for teaching and learning. This paper proposal that course content development begins with basic content, enhanced content and extended content, and in line with the basic experiments, comprehensive experiments and designing experiments focusing on applied data analysis case.

Study in the process of teaching. Research of teaching process carries through three ways in theory, experiment and practice. Theoretical teaching research and optimize the application and the evaluation programs of risk management based on curriculum standards, to increase students' confidence, means and methods of learning. Experimental teaching researches three-level experiments and experimental teaching programs, and designs the corresponding test report, as well as the evaluation program. In terms of social practice, social practical ways and means of implementation are researched to guide students to actively participate, as well as to track the whole process of social evaluation of the program.
TABLE II. The "1+2" Mode

\begin{tabular}{|c|c|c|}
\hline Model & Context & Content \\
\hline \multirow{3}{*}{$\begin{array}{l}\text { Standard- } \\
\text { setting }\end{array}$} & $\begin{array}{l}\text { curriculum } \\
\text { standards }\end{array}$ & $\begin{array}{c}\text { 1.courses nature } \\
\text { 2.course objective } \\
\text { 3.content objective } \\
\text { 4.implementation recommendation }\end{array}$ \\
\hline & $\begin{array}{l}\text { teaching quality } \\
\text { standard }\end{array}$ & $\begin{array}{c}\text { 1.set level of contents of the course } \\
\text { 2. set level of teaching } \\
\text { 3.evaluation }\end{array}$ \\
\hline & $\begin{array}{l}\text { training quality } \\
\text { standard }\end{array}$ & $\begin{array}{l}\text { 1. set level of training } \\
\text { 2.evaluation }\end{array}$ \\
\hline \multirow{3}{*}{$\begin{array}{c}\text { Course } \\
\text { content } \\
\text { development }\end{array}$} & basic content & $\begin{array}{c}\text { 1.basic concept \& theory } \\
\text { 2.basic experiment } \\
\text { 3.comprehensive experiment }\end{array}$ \\
\hline & $\begin{array}{l}\text { enhanced } \\
\text { content }\end{array}$ & $\begin{array}{l}\text { 1.comprehensive experiment } \& \text { case } \\
\text { 2.designing experiment }\end{array}$ \\
\hline & extended content & $\begin{array}{c}\text { 1.comprehensive experiment \&case } \\
\text { 2.designing experiment } \\
\text { 3.social practice }\end{array}$ \\
\hline \multirow{3}{*}{$\begin{array}{l}\text { Study in the } \\
\text { process of } \\
\text { teaching }\end{array}$} & theory & $\begin{array}{l}1 \text { teaching content and optimization } \\
\text { 2. evaluation scheme }\end{array}$ \\
\hline & experiment & $\begin{array}{l}\text { 1.design of the case } \\
\text { 2.design of the experimental report } \\
\text { 3. evaluation scheme }\end{array}$ \\
\hline & practice & $\begin{array}{l}\text { 1. actively participation } \\
\text { 2. evaluation scheme }\end{array}$ \\
\hline
\end{tabular}

\section{CONCLUSION}

The paper proposed "1+2" construction system of application-oriented courses in risk management. The course standard is proof of teaching, evaluation and examination. Employing "1+2" mode is given coherence in overall thinking standards, textbooks, teaching and evaluation. However, how to develop risk management standards in line with applicationoriented features, how to develop the curriculum standards of risk management course content and curriculum standards, which is not out of line with curriculum content and content, and how to research the effective and credible evaluation program met various aspects are the focus of curriculum construction problems.

\section{ACKNOWLEDGEMENT}

This research was financially supported by the Discipline Construction Project (No. XXKPY1604) of Shanghai Second Polytechnic University and the MOE (Ministry of Education in China) Project of Humanities and Social Sciences (No.C81RW14S003).

\section{REFERENCES}

[1] P. Hopkin, R.Y. Cai, trans. Risk Management. Beijing: China Railway Pres, 2014.

[2] D. Wang. Summary on Risk Management Theory Abroad. Journal of Financial Development Research, 2011, No.2: 25-29. (In Chinese)

[3] C.H. Ye. Analysis of Evolution Features of Foreign Risk Management Theory. Journal of Guangxi University of Finance and Economics, 2014, No.3: 19-24. (In Chinese)

[4] W. Wang, D. Wang. The Evolution and Review of Enterprise Risk Management Theory. Auditing Research, 2010, No.4: 96-100. (In Chinese) 
[5] Z. Wang, R.H. Huang. Theories, Methods and Progress of Foreign Risk Management Research. Foreign Economies \& Management, 2005, No.2: 25-31. (In Chinese)

[6] Q. Zhang, L.Q. Cheng. Review on Theory and The Latest Research Trends of Risk Management. Financial Theory \& Practice, 2008, No.10: 105-109. (In Chinese)

[7] Z.G. Cheng. The Comparative Study of Traditional Risk Management Theory and Modern Risk Management Theory. Journal of Insurance Professional College, 2007, No.6: 15-18. (In Chinese)

[8] C. Harry, W. C. Mair. II. Quantitative Risk Management. Enterprise Risk Management and COSO: A Guide for Directors, Executives, and Practitioners. John Wiley \& Sons, Inc. 2015.
[9] Z.W. Wang, B.S. Cui. Research on the Design, Development and Application of Risk Management Training System. Journal of Finance and Management Research, 2015, No.1: 48-54. (In Chinese)

[10] C.M. Anderson. Quantitative Risk Management: Concepts, Techniques, and Tools. Journal of the American Statistical Association, 2006 , 101(476):1731-1732.

[11] M. Thomas, P. Embrechts, R. A. Davis. The Mathematics and Statistics of Quantitative Risk Management. Oberwolfach Reports, 2012, 9(2012):351-396

[12] F. Li. Standards-based Instruction Design. Shanghai: East China Normal University Press, 2013. (In Chinese) 